\title{
PENGARUH PROMOSI, HARGA DAN KUALITAS PRODUK TERHADAP KEPUTUSAN PEMBELIAN SMARTPHONE VIVO PADA MASYARAKAT KOTA YOGYAKARTA
}

\author{
Endy Yudha Prawira \\ endyprecel1927@gmail.com \\ Universitas Ahmad Dahlan \\ Sukardi \\ sukardi_feuad@yahoo.com \\ Universitas Ahmad Dahlan
}

\begin{abstract}
ABSTRAK
This study aims to determine the effect of promotion, price, and product quality for Smartphone purchase decisions VIVO The population of this research is the consumers of the city community Yogyakarta which is more than 17 years old and has already been make purchases of VIVO Smartphone products and samples used as many as 95 consumers in Yogyakarta, community engineering Sampling in this study is Purposive Sampling. The data analysis tool used is a linear regression test multiple. The results of this study indicate that promotions and Product quality has a significant effect on purchasing decisions while the price does not significantly influence the decision purchase. Simultaneously promotion, price, and quality variables significant effect on purchasing decisions. Promotion factor, price, and product quality affect purchasing decisions of $24.1 \%$ while the remaining $75.9 \%$ is influenced by Other variables that are not present in this study. Researchers expected can test variables other than product promotion, price, and quality to make a purchase decision.
\end{abstract}

Keywords: Product Purchasing, Promotion, Price and Quality Decisions.

\begin{abstract}
PENDAHULUAN
Perkembangan di era modern saat ini adalah teknologi informasi dankomunikasi. Teknologi informaasi dan komunikasi kini menjadi kebutuhan yang penting bagi kalangan masyarakat. Kebutuhan tersebut berdampak pada meningkatnya permintaan akan berbagai jenis alat komunikasi yang mengakibatkan semakin banyaknya persaingan dalam dunia bisnis dibidang telekomunikasi. Hal tersebut bisa dilihat dari banyaknya produsen yang membuat produk-produk alat komunikasi (Smartphone) yang menawarkan jenis produk baru dengan inovasi dari produk sebelumnya yang sudah beredar dikalangan masyarakat.
\end{abstract}


smartphone menimbulkan banyak persaingan bisnis di dalam industri teknologi informasi dan komunikasi.

Smartphone adalah telepon genggam yang memiliki kemampuan dengan penggunaan dan fungsi yang menyerupai komputer. Belum ada standar pabrik yang menentukan arti smartphone tersebut. Bagi beberapa orang smartphone merupakan telepon yang bekerja menggunakan seluruh perangkat lunak sistem operasi yang menyediakan hubungan standar dan mendasar bagi pengembang aplikasi. Kini para produsen smartphone harus terus mengembangkan produk yang dipasarkan agar dapat dimanfaatkan semaksimal mungkin oleh konsumen. Sebaliknya, para konsumen saat ini tidak hanya membeli sebuah barang atau jasa, tetapi aspek promosi, harga, dan kualitas produk harus dipikirkan. Oleh sebab itu produsen harus mempunyai strategi pemasaran yang tepat agar mampu bersaing dengan perusahaan lain.

Menurut Tjiptono (2002) dalam Amalia dan Oloan (2017) promosi adalah bentuk komunikasi pemasaran, artinya aktivitas pemasaran yang berusaha menyebarkan informasi, mempengaruhi atau membujuk dan mengingatkan pasar sasaran atas perusahaan dan produknya agar bersedia menerima, membeli dan loyal pada produk yang ditawarkan perusahaan yang bersangkutan. Harga adalah sejumlah uang yang harus dibayar konsumen untuk mendapatkan sebuah produk atau jasa (Alma, 2007). Dalam kehidupan bisnis, harga merupakan salah satu faktor penting yang mempengaruhi pemasaran suatu produk. Tinggi rendahnya harga selalu menjadi perhatian utama para konsumen saat mereka mencari suatu produk. Kualitas produk adalah kemampuan produk untuk melaksanakan fungsi-fungsinya, kemampuan itu meliputi daya tahan, keandalan, daan atribut lain yang berharga pada produk secara keseluruhan (Kotler, 2008) dalam Amalia dan Oloan (2017).
Kualitas produk yang baik tentu akan menarik minat konsumen untuk membeli, karena konsumen menginginkan membeli produk yang berkualitas.

Banyak perusahaan mengandalkan kepuasan konsumen sebagai jaminan keberhasilan dikemudian hari, tetapi kemudian kecewa mendapati bahwa para konsumennya yang merasa puas dapat membeli produk pesaing tanpa ragu-ragu (Griffin, 2003) dalam Sulistya, (2014). Pemasar pada umumnya menginginkan bahwa pelanggan yang diciptakannya dapat dipertahankan selamanya. Ini bukan tugas yang mudah mengingat perubahanperubahan dapat terjadi setiap saat, baik perubahan pelanggan pada diri pelanggan seperti selera maupun aspek-aspek psikologis serta perubahan kondisi lingkungan yang mempengaruhi aspekaspek psikologis, sosial dan kultural pelanggan (Swastha, 1999).

Sebuah merek smartphone global dari China yang fokus pada memperkenalkan kualitas suara sempurna (musik) dan fotografi (kamera) dengan teknologi mutakhir, Vivo mengembangkan produk yang dinamis dan bergaya muda serta penuh gairah. Vivo mengembangkan dan memproduksi smartphone, aksesoris smartphone, perangkat lunak dan layanan online. Didirikan pada tahun 2009, Vivo dengan cepat meluas kepasar india dan asia tenggara. Vivo berdedikasi untuk mengejar kesempurnaan dan terusmenerus menciptakan kejutan untuk pengguna melalui inovasi yang terusmenerus. Vivo menpunyai visi menjdi distributor nomor satu dalam menyediakan smartphone di Indonesia. Dan dia juga memiliki misi memberikan produk dan layanan inovatif, meningkatkan kualitas SDM (sumber daya manusia) dengan cara memberikan pelatihan kepada karyawan baik produk maupun layanan, meningkatkan channel distribusi produk Vivo baik offline maupun online supaya mudah dijangkau oleh konsumen. 
Merintis penggunaan $\mathrm{Hi}-\mathrm{Fi}$ audio chip di smartphone, Vivo menciptakan smartphone pertama dengan chip $\mathrm{Hi}-\mathrm{Fi}$, $\mathrm{X} 1$. Sejak itu Vivo tetap berkomitmen untuk memberikan pengalaman audio terbaik kepada pelanggan. Produk kamera smartphone Vivo merupakan salah satu keunggulan yang paling penting. Fotografi adalah cara bagi orang untuk mengekpresikan diri dan berbagi kegembiraan dengan orang lain. Melalui smatphone ini Vivo menawarkan kepada pengguna solusi fotografi kelas profesional, mengambil fotografi ketingkat bentuk seni, menyaksikan dan merekam semua momen indah kehidupan.

Saat ini walaupun terbilang produk pendatang baru, Vivo mencoba dipasar yang masih sangat bergairah tersebut dengan membawa beberapa seri smartphone ketanah air diantaranya yaitu: Vivo V11, V9, V7+, V7, Y95, Y93,Y91, Y83, Y81, Y71, dll. Meski terbilang produk baru mereka tidak main-main untuk memproduksi smartphone, dan juga Vivo termasuk berani, karena tiga diantara lini yang dijadikan smartphone yang dijadikan uutuk menyasar kelas menegah dan kelas premium. Kini Vivo sangat gencar mempromosikan produknya di media elektronik dan media cetak. Dengan spesifikasi, fitur-fitur dan harga yang ditawarkan smartphone Vivo menjamin kualitas produknya.

Tujuan dari penelitian ini di antaranya: 1) untuk mengetahui apakah promosi berpengaruh terhadap keputusan pembelian produk smartphone VIVO pada masyarakat kota Yogyakarta, 2) untuk mengetahui apakah harga berpengaruh terhadap keputusan pembelian produk smartphone VIVO pada masyarakat kota Yogyakarta, 3) untuk mengetahui apakah kualitas produk berpengaruh terhadap keputusan pembelian smartphone VIVO pada masyarakat kota Yogyakarta dan 4) untuk mengetahui apakah promosi, harga, dan kualitas produk berpengaruh simultan terhadap keputusan pembelian smartphone VIVO pada masyarakat kota Yogyakarta.

\section{REVIEW LITERATUR DAN HIPOTESIS}

\section{Landasan Teori}

1. Kepuasan Pembelian

Keputusan pembelian adalah tindakan dari konsumen untuk membeli atau tidak terhadap suatu produk (Kotler, 2002) dalam Sulistya (2015). Dari berbagai faktor yang mempengaruhi konsumen dalam melakukan pembelian suatu produk atau jasa, konsumen selalu mempertimbangkan kualitas, harga dan produk yang sudah dikenal oleh masyarakat. Konsumen sebelum memutuskan untuk membeli, biasanya melalui beberapa tahap terlebih dahulu yaitu, (1) pengenalan masalah, (2) pencarian informasi, (3) evaluasi alternatif, (4) keputusan membeli atau tidak, (5) perilaku pasca pembelian.

\section{Promosi}

Menurut Tjiptono (2015) dalam Ratnaningrum (2016), promosi merupakan salah satu faktor penentu keberhasilan program pemasaran. Kotler (2001) menambahkan bahwa promosi adalah aktifitas yang mengkomunikasikan keunggulan produk dan membujuk pelanggan sasaran untuk membelinya.

\section{Harga}

Menurut Kotler (2009) dalam Mandey (2013) menyatakan bahwa harga adalah elemen dalam bauran pemasaran yang tidak saja menentukan profitabilitas tetapi juga sebagai sinyal untuk mengkomunikasikan proporsi nilai suatu produk. 
4. Kualitas Produk

Menurut Kotler (2004) dalam

Rizki (2015) kualitas produk adalah kemampuan suatu produk untuk melakukan fungsi-fungsinya, meliputi daya tahan, kehandalaan, ketelitian yang dihasilkan, kemudahan dioprasikan dan diperbaiki, dan atribut lain yang berharga pada produk secara keseluruhan.

\section{Penelitian Terdahulu}

Gerung (2017) melakukan penelitian dengan judul "Pengaruh Kualitas Produk, Harga, dan Promosi Terhadap Keputusan Pembelian Mobil Nissan X-Trail Pada PT. Wahana Wirawan Manado". Hasilnya Kualitas Produk, Harga, dan Promosi berpengaruh signifikan terhadap Keputusan Pembelian Nissan X-Trail pada PT. Wahana Wirawan Manado.

Ratnaningrum (2016) melakukan penelitian dengan judul "Pengaruh Promosi, Harga, Kualitas Produk Terhadap Keputusan Pembelian Konsumen dalam Pembelian Bahan Bakar Minyak Jenis Pertalite di Yogyakarta". Hasilnya Promosi dan Harga berpengaruh signifikan terhadap Keputusan Pembelian, sedangkan Kualitas Produk tidak berpengaruh signifikan terhadap Keputusan Pembelian.

\section{Hipotesis}

H1: Promosi berpengaruh signifikan terhadap keputusan pembelian.

$\mathrm{H} 2$ : Harga berpengaruh signifikan terhadap keputusan pembelian.
H3: Kualitas produk berpengaruh signifikan terhadap keputusan pembelian.

H4: Promosi, Harga, dan Kualitas Produk secara simultan berpengaruh terhadap Keputusan Pembelian

\section{METODE PENELITIAN}

\section{Populasi dan Sampel}

Menurut Sugiyono (2014) populasi adalah wilayah generalisasi yang terdiri atas obyek atau subyek yang mempunyai kualitas dan karakteristik tertentu yang ditetapkan oleh peneliti untuk dipelajari dan kemudian ditarik kesimpulannya. Populasi merupakan sekumpulan elemen atau unsur ( bisa berupa manusia, hewan, tumbuhan, benda, gejala, nialai tes, atau peristiwa) yang menjadi objek penelitian. Populasi yang digunakan dalam penelitian ini adalah konsumen masyarakat kota Yogyakarta yang berumur lebih dari 17 tahun dan sudah pernah melakukan pembelian produk Smartphone VIVO.

Sugiyono (2014) menjelaskan bahwa sampel adalah bagian dari jumlah dari karakteristik yang dimiliki oleh populasi tersebut. Sampel merupakan bagian dari populasi yang ada, sehingga untuk pengambilan sampel harus menggunakan cara tertentu yang didasarkan oleh pertimbangan-pertimbangan yang ada. Sampel pada penelitian ini adalah sebagiam konsumen masyarakat kota Yogyakarta yang berumur lebih dari 17 tahun dan sudah pernah melakukan pembelian produk Smartphone VIVO.

Teknik pengambilan sampel yang digunakan dalam penelitian ini adalah Purposive Sampling, yaitu teknik pengambilan sempel dengan pertimbangan tertentu. Cara menentukan sampel penelitian ini adalah dengan mengajukan pertanyaan kepada calon responden apakah calon responden ini pernah melakukan pembelian produk Smartphone VIVO atau belum. Jika calon responden sudah pernah melakukan pembelian maka dia menjadi responden yang terpilih. 


\section{Definisi Operasional}

1. Variabel Independen

a. Promosi

Promosi adalah aktifitas yang mengkomunikasikan keunggulan produk dan menbujuk pelanggan sasaran untuk membelinya. Oleh karena itu perusahaan sebaiknya memasang iklan, melaksanakan promosi penjualan, mengatur publikasi, dan menyebarkan trnaga penjualan untuk mempromosikan produkproduknya. Indikator yang digunakan dalam variabel ini adalah iklan di media elektronik, iklan melalui media cetak dan adanya promosi penjualan, misalnya memberikan bonus atau hadiah

b. Harga

Harga merupakan elemen dalam bauran pemasaran yang tidak saja menentukan profitabilitas tetapi juga sebagai sinyal unruk mengkomunikasikan proporsi nilai suatu produk. Indikator yang digunakan dalam variabel ini adalah keterjangkauan harga, kesesuaian harga dengan kualitas, daya saing harga dan kesesuaian harga dengan manfaat.

c. Kualitas Produk

Kualitas produk merupakan kemampuan suatu produk untuk melakukan fungsi-fungsinya, kemampuan tersebut meliputi daya tahan, kehandalan, ketelitian yang dihasilkan, kemudahan dioperasikan dan diperbaiki, dan atribut lain yang berharga pada produk secara keseluruhan. Indikator yang digunakan dalam variabel ini adalah kinerja, daya tahan, kesesuaian dengan spesifikasi, fitur, reliabilitas, estetika dan kesan kualitas.
2. Variabel Dependen

Dalam penelitian ini variabel dependen adalah keputusan pembelian. Keputusan pembelian adalah tindakan dari konsumen untuk mau membeli atau tidak suatu produk. Indikator yang digunakan dalam variabel ini adalah keputusan pembelian karena kualitas produk, keputusan pembelian karena harga produk dan keputusan pembelian karena keinginan dan kebutuhan.

\section{Uji Instrumen}

\section{Uji Validitas}

Uji validitas digunakan untuk mngetahui valid atau tidaknya suatu kuesioner. Suatu kuesioner dapat dikatakan valid apabila pertanyaan pada kuesioner mampu mengungkapkan sesuatu yang akan diukur oleh kuesioner tersebut. Alat ukur yang digunakan dalam penelitian ini adalah teknik Korelasi Product Moment. Dalam penelitian ini, apabila $\mathrm{r}$ hitung $\geq \mathrm{r}$ tabel dengan $\alpha=0.05$ maka variabel tersebut dinyatakan valid, dan sebaliknya apabila $r$ hitung $\leq \mathrm{r}$ tabel maka variabel tersebut dinyatakan tidak valid.

\section{Uji Reliabilitas}

Menurut Sugiyono penelitian dikatakan reliable apabila instrumen itu cukup baik sehingga mampu mengungkap data yang dipercaya. Dalam penelitian ini uji reliabilitas menggunakan rumus Cronbach Alpha. Suatu variabel atau konstruk dapat dikatakan reliabel jika memberikan nilai Cronbach Alpha lebih besar dari 0,60 (Sugiyono, 2014). 


\section{Teknik Analisis Data}

1. Analisis Regresi Berganda

Teknik yang digunakan dalam penelitian ini adalah analisis regresi linier berganda. Analisis regresi linier berganda adalah teknik statistik yang digunakan untuk mengetahui pengaruh variabel independen terhadap variabel dependen. Rumus persamaan regresi tersebut adalah sebagai berikut:

Rumus: $\mathrm{Y}=\mathrm{a}+b 1 \times 1+b 2 \times 2+b 3 \times 3$

$\mathrm{Y}=$ Keputusan Pembelian

$\mathrm{a}=$ Konstanta

$b 1=$ Koefisien regresi variabel promosi

$b 2=$ Koefisien regresi variabel harga

$b 3=$ Koefisien regresi variabel kualitas produk

$x 1=$ Promosi

$x 2=$ Harga

$x 3=$ Kualitas Produk

2. Uji Parsial (Uji T)

Menurut Ghozali dalam Musthofa (2018), uji statistik t pada dasarnya menunjukkan seberapa jauh pengaruh satu variabel independen secara individual dalam menerangkan variabel dependen. Pengujian dilakukan dengan menggunakan signifikansi level $0,05(\alpha=5 \%)$. Uji ini dilakukan untuk membandingkan thitung dengan t tabel, yaitu mengetahui apakah variabel independen $(\mathrm{X})$ berpengaruh signifikan terhadap variabel dependen $(\mathrm{Y})$.

Jika tingkat signifikansi $<0,05$, maka $\mathrm{H} 0$ ditolak dan Ha diterima.

Jika tingkat signifikansi > 0,05, maka HO diterima dan Ha ditolak.

\section{Uji Simultan (Uji F)}

Pengujian pengaruh variabel bebas secara bersama-sama terhadap variabel terikatnya dapat dilakukan dengan menggunakan uji F. Uji F pada dasarnya menunjukkan apakah smua variabel independen (X) secara bersama-sama dapat berpengaruh terhadap variabel dependen $(\mathrm{Y})$.
Jika signifikansi > alpha 0,05 maka $\mathrm{H} 0$ diterima dan Ha di tolak.

Jika signifikansi < alpha 0,05 maka H0 ditolak dan Ha diterima.

\section{Uji Koefisien Determinasi}

Koefisien determinasi ( $R 2)$ pada intinya mengukur seberapa jauh kemampuan sebuah model menerangkan variabel dependen. Menurut Ghozali dalam Musthofa (2018), nilai koefisien determinasi adalah antara 0 sampai 1 . Nilai $R 2$ yang kecil berarti kemampuan variabelvariabel independen dalam menjelaskan variabel dependen sangat terbatas. Nilai yang mendekati 1 berarti variabelvariabel independen memberikan hampir semua informasi yang dibutuhkan untuk memprediksi variabel-variabel dependen.

\section{HASIL PENELITIAN DAN PEMBAHASAN}

\section{Hasil Analisis Responden}

Responden dalam penelitian ini adalah sebagian Masyarakat Kota Yogyakarta yang pernah membeli, memiliki, dan akan membeli Smartphone VIVO. Karakteristik responden berdasarkan tinggal di kecamatan, jenis kelamin, usia, pekerjaan, penghasilan, pernah membeli Smartphone VIVO, yang telah disusun pada tabel di bawah ini:

\begin{tabular}{|c|c|c|c|}
\hline \multicolumn{4}{|c|}{ Karakteristik Responden Berdasarkan Tempat Tinggal } \\
\hline \multirow{4}{*}{ Keterangan } & $\begin{array}{c}\text { Frekuensi } \\
\text { (Orang) }\end{array}$ & Persentase (\%) \\
\hline \multirow{5}{*}{ Kecamatan } & Gedongtengen & 4 & $4.71 \%$ \\
\cline { 2 - 4 } & Gondokusuman & 4 & $4.71 \%$ \\
\cline { 2 - 4 } & Gondomanan & 7 & $8.24 \%$ \\
\cline { 2 - 4 } & Jetis & 2 & $2.35 \%$ \\
\cline { 2 - 4 } & Kotagede & 10 & $11.76 \%$ \\
\cline { 2 - 4 } & Kraton & 1 & $1.18 \%$ \\
\cline { 2 - 4 } & Margangsan & 1 & $1.18 \%$ \\
\cline { 2 - 4 } & Ngampilan & 2 & $2.35 \%$ \\
\cline { 2 - 4 } & Pakualaman & 2 & $2.35 \%$ \\
\cline { 2 - 4 } & Tegalrejo & 1 & $1.18 \%$ \\
\cline { 2 - 4 } & Umbulharjo & 49 & $57.65 \%$ \\
\cline { 2 - 4 } & Wirobrajan & 2 & $2.35 \%$ \\
\hline & Total & 85 & $100 \%$ \\
\hline
\end{tabular}

1. Responden yang tinggal di kecamatan Gedongtengen 4 orang atau $4,71 \%$ dari total responden sebanyak 85 orang. 
2. Responden yang tinggal di kecamatan Gondokusuman 4 orang atau 4,71\% dari total responden sebanyak 85 orang.

3. Responden yang tinggal di kecamatan Gondomanan 7 orang atau $8,24 \%$ dari total responden sebanyak 85 orang.

4. Responden yang tinggal di kecamatan Jetis 2 orang atau 2,35\% dari total responden sebnayak 85 orang.

5. Responden yang tinggal di kecamatan Kotagede 10 orang atau $11,76 \%$ dari total responden sebanyak 85 orang.

6. Responden yang tinggal di kecamatan Kraton 1 orang atau $1,18 \%$ dari total responden sebanyak 85 orang.

7. Reponden yang tinggal di kecamatan Margangsan 1 orang atau $1,18 \%$ dari total responden sebanyak 85 orang.

8. Responden yang tinggal di kecamatan Ngampilan 1 orang atau 2,35\% dari total responden sebanyak 85 orang.

9. Responden yang tinggal di kecamatan Pakualaman 2 orang atau 2,35\% dari total responden sebanyak 85 orang.

10. Responden yang tinggal di kecamatan Tegalrejo 1 orang atau $1,18 \%$ dari total responden sebanyak 85 orang.

11. Responden yang tinggal di kecamatan Umbulharjo 49 orang atau $57,65 \%$ dari total responden sebanyak 85 orang.

12. Responden yang tinggal di kecamatan Wirobrajan 2 orang atau $2,35 \%$ dari total responden sebanyak 85 orang.

\begin{tabular}{|c|c|c|c|}
\hline \multicolumn{4}{|c|}{ Karakteristik Responden Berdasarkan Jenis Kelamin } \\
\hline \multicolumn{2}{|c|}{ Keterangan } & $\begin{array}{c}\text { Frekuensi } \\
\text { (Orang) }\end{array}$ & Persentase (\%) \\
\hline \multirow{2}{*}{$\begin{array}{c}\text { Jenis } \\
\text { Kelamin }\end{array}$} & Laki-laki & 41 & $48,24 \%$ \\
\cline { 2 - 4 } & Perempuan & 44 & $51,76 \%$ \\
\hline \multicolumn{2}{|c|}{ Total } & 85 & $100 \%$ \\
\hline
\end{tabular}

1. Responden yang berjenis kelamin lakilaki 41 orang atau $48,24 \%$ dari total responden sebanyak 85 orang.

2. Responden yang berjenis kelamin perempuan 44 orang atau $51,76 \%$ dari total responden sebanyak 85 orang.

\begin{tabular}{|l|c|c|c|}
\hline \multicolumn{4}{|c|}{ Karakteristik Responden Berdasarkan Usia } \\
\hline \multirow{2}{*}{ Keterangan } & $\begin{array}{c}\text { Frekuensi } \\
\text { (Orang) }\end{array}$ & Persentase (\%) \\
\hline \multirow{3}{*}{ Usia } & $17-21$ & 37 & $43,53 \%$ \\
\cline { 2 - 4 } & $22-26$ & 40 & $47,06 \%$ \\
\cline { 2 - 4 } & $26-30$ & 8 & $9,41 \%$ \\
\hline
\end{tabular}

1. Responden yang berusia 17-21 tahun 37 orang atau $43,53 \%$ dari total responden sebanyak 85 orang.

2. Responden yang berusia 22-26 tahun 40 orang atau $47,06 \%$ dari total responden sebanyak 85 orang.

3. Responden yang berusia 26- 30 tahun 8 orang atau $9,41 \%$ dari total responden sebanyak 85 orang.

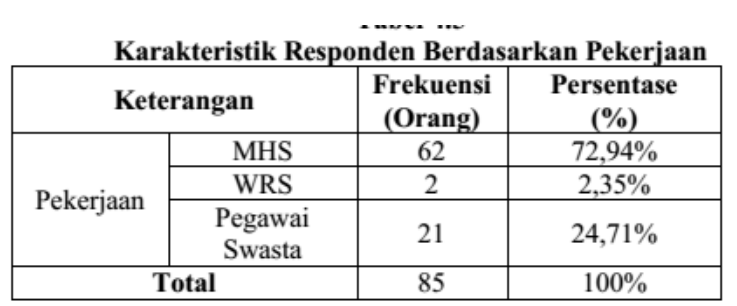

1. Responden yang mahasiswa 62 orang atau $72,94 \%$ dari total responden sebanyak 85 orang.

2. Responden yang bekerja sebagai wiraswasta 2 orang atau $2,35 \%$ dari total responden sebanyak 85 orang.

3. Responden yang bekerja sebagai pegawai swasta 21 orang atau 24,71\% dari total responden sebanyak 85 orang.

\begin{tabular}{|c|c|c|c|}
\hline \multicolumn{4}{|c|}{ Karakteristik Responden Berdasarkan Penghasilan } \\
\multicolumn{2}{|c|}{ Keterangan } & $\begin{array}{c}\text { Frekuensi } \\
\text { (Orang) }\end{array}$ & Persentase (\%) \\
\hline \multirow{4}{*}{ Penghasilan } & $<1.500 .000$ & 57 & $67,06 \%$ \\
\cline { 2 - 4 } & $\begin{array}{c}1.500 .000- \\
2.500 .000\end{array}$ & 24 & $28,24 \%$ \\
\cline { 2 - 4 } & $\begin{array}{c}2.500 .000- \\
3.500 .000\end{array}$ & 3 & $3,53 \%$ \\
\cline { 2 - 4 } & $>3.500 .000$ & 1 & $1,18 \%$ \\
\hline \multicolumn{2}{|c|}{ Total } & 85 & $100 \%$ \\
\hline
\end{tabular}

1. Responden yang berpenghasilan $<\mathrm{Rp}$. 1.500 .000 ada 57 orang atau $67,06 \%$ dari total responden sebanyak 85 orang.

2. Responden yang berpenghasilan $\mathrm{Rp}$. 1.500 .000 - Rp. 2.500 .000 ada 24 orang atau $28,24 \%$ dari total responden sebanyak 85 orang. 
3. Responden yang berpenghasilan $\mathrm{Rp}$. 2.500 .000 - Rp. 3.500 .000 ada 3 orang atau $3,53 \%$ dari total responden sebanyak 85 orang.

4. Responden yang berpenghasilan > Rp. 3.500.000 ada 1 orang atau $1,18 \%$ dari total responden sebanyak 85 orang.

\section{Hasil Penelitian}

1. Hasil Uji Validitas

a. Keputusan Pembelian

\begin{tabular}{|c|c|c|c|c|}
\hline Keputusan Pembelian (Tahap Pertama) \\
\hline Item & $\mathbf{r}_{\text {hitung }}$ & $\begin{array}{c}\mathbf{r}_{\text {tabel }} \\
\mathbf{5 \%} \mathbf{( 3 0 )}\end{array}$ & Sig & Kriteria \\
\hline KP.1.1 & 0,569 & 0,349 & 0,001 & Valid \\
\hline KP.1.2 & 0,723 & 0,349 & 0,000 & Valid \\
\hline KP.2.1 & 0,724 & 0,349 & 0,000 & Valid \\
\hline KP.2.2 & 0,200 & 0,349 & 0,290 & Tidak Valid \\
\hline KP.3.1 & 0,728 & 0,349 & 0,000 & Valid \\
\hline KP.3.2 & 0,479 & 0,349 & 0,007 & Valid \\
\hline
\end{tabular}

Setelah diuji diketahui bahwa terdapat 1 item yang tidak valid yaitu KP.2.2 maka kriteria tidak valid diuji kembali dengan cara menghilangkan atau membuang item tersebut satu persatu menggunakan SPSS versi 20 dengan hasil akhir sebagai berikut:

Keputusan Pembelian (Tahap Terakhir)
\begin{tabular}{|c|c|c|c|c|}
\hline Item & $\mathbf{r}_{\text {hitung }}$ & $\begin{array}{c}\mathbf{r}_{\text {tabel }} \\
\mathbf{5 \%} \mathbf{( 3 0 )}\end{array}$ & Sig & Kriteria \\
\hline KP.1.1 & 0,569 & 0,349 & 0,001 & Valid \\
\hline KP.1.2 & 0,723 & 0,349 & 0,000 & Valid \\
\hline \multicolumn{5}{|l|}{} \\
\hline KP.2.1 & 0,724 & 0,349 & 0,000 & Valid \\
\hline KP.3.1 & 0,728 & 0,349 & 0,000 & Valid \\
\hline KP.3.2 & 0,479 & 0,349 & 0,007 & Valid \\
\hline
\end{tabular}

b. Promosi

\begin{tabular}{|c|c|c|c|c|}
\multicolumn{7}{c|}{ Promosi (Tahap Pertama) } \\
\hline Item & rhitung & $\begin{array}{c}\text { rtabel } \\
\mathbf{5 \%} \mathbf{( 3 0 )}\end{array}$ & Sig & Kriteria \\
\hline P.1.1 & 0,441 & 0,349 & 0,015 & Valid \\
\hline P.1.2 & 0,705 & 0,349 & 0,000 & Valid \\
\hline P.2.1 & 0,727 & 0,349 & 0,000 & Valid \\
\hline P.2.2 & 0,299 & 0,349 & 0,108 & Tidak Valid \\
\hline P.3.1 & 0,491 & 0,349 & 0,006 & Valid \\
\hline P.3.2 & 0,635 & 0,349 & 0,000 & Valid \\
\hline
\end{tabular}

Setelah diuji diketahui bahwa terdapat 1 item yang tidak valid yaitu P.2.2 maka kriteria tidak valid diuji kembali dengan cara menghilangkan atau membuang item tersebut satu persatu menggunakan SPSS versi 20 dengan hasil akhir sebagai berikut:

Promosi (Tahap Terakhir)
\begin{tabular}{|c|c|c|c|c|}
\hline Item & rhitung & $\begin{array}{c}\mathbf{r}_{\text {tabel }} \\
\mathbf{5 \%} \mathbf{( 3 0 )}\end{array}$ & Sig & Kriteria \\
\hline P.1.1 & 0,441 & 0,349 & 0,015 & Valid \\
\hline P.1.2 & 0,705 & 0,349 & 0,000 & Valid \\
\hline P.2.1 & 0,727 & 0,349 & 0,000 & Valid \\
\hline P.3.1 & 0,491 & 0,349 & 0,006 & Valid \\
\hline P.3.2 & 0,635 & 0,349 & 0,000 & Valid \\
\hline
\end{tabular}

c. Harga

\begin{tabular}{|c|c|c|c|c|}
\multicolumn{7}{c}{ Harga (Tahap Pertama) } \\
\hline Item & rhitung & $\begin{array}{c}\text { rtabel } \\
\mathbf{5 \%} \mathbf{( 3 0 )}\end{array}$ & $\mathbf{~ S i g ~}$ & Kriteria \\
\hline H.1.1 & 0,309 & 0,349 & 0,096 & Tidak Valid \\
\hline H.1.2 & 0,574 & 0,349 & 0,001 & Valid \\
\hline H.2.1 & 0,654 & 0,349 & 0,000 & Valid \\
\hline H.2.2 & 0,309 & 0,349 & 0,096 & Tidak Valid \\
\hline H.3.1 & 0,400 & 0,349 & 0,028 & Valid \\
\hline H.3.2 & 0,531 & 0,349 & 0,003 & Valid \\
\hline H.4.1 & 0,476 & 0,349 & 0,008 & Valid \\
\hline H.4.2 & 0,739 & 0,349 & 0,000 & Valid \\
\hline
\end{tabular}

Setelah diuji diketahui bahwa terdapat 2 item yang tidak valid yaitu H.1.1 dan H.2.2 maka kriteria tidak valid diuji kembali dengan cara menghilangkan atau membuang item tersebut satu persatu menggunakan SPSS versi 20 dengan hasil akhir sebagai berikut:

\begin{tabular}{|c|c|c|c|c|}
\hline Item & rhitung & $\begin{array}{c}\text { rtabel } \\
\mathbf{5 \%} \mathbf{( 3 0 )}\end{array}$ & Sig & Kriteria \\
\hline H.1.2 & 0,574 & 0,349 & 0,001 & Valid \\
\hline H.2.1 & 0,654 & 0,349 & 0,000 & Valid \\
\hline H.3.1 & 0,400 & 0,349 & 0,028 & Valid \\
\hline H.3.2 & 0,531 & 0,349 & 0,003 & Valid \\
\hline H.4.1 & 0,476 & 0,349 & 0,008 & Valid \\
\hline H.4.2 & 0,739 & 0,349 & 0,000 & Valid \\
\hline
\end{tabular}

d. Kualitas Produk

\begin{tabular}{|c|c|c|c|c|}
\hline Kualitas Produk (Tahap Pertama) \\
\hline Item & rhitung $^{\text {rtabel }}$ & $\mathbf{5 \% ( 3 0 )}$ & Sig & Kriteria \\
\hline K.1.1 & 0,027 & 0,349 & 0,886 & Tidak Valid \\
\hline K.1.2 & 0,781 & 0,349 & 0,000 & Valid \\
\hline K.2.1 & 0,531 & 0,349 & 0,003 & Valid \\
\hline K.2.2 & 0,490 & 0,349 & 0,006 & Valid \\
\hline K.3.1 & 0,114 & 0,349 & 0,548 & Tidak Valid \\
\hline K.3.2 & 0,665 & 0,349 & 0,000 & Valid \\
\hline K.4.1 & 0,598 & 0,349 & 0,000 & Valid \\
\hline K.4.2 & 0,397 & 0,349 & 0,030 & Valid \\
\hline K.5.1 & 0,644 & 0,349 & 0,000 & Valid \\
\hline K.5.2 & 0,476 & 0,349 & 0,008 & Valid \\
\hline K.6.1 & 0,407 & 0,349 & 0,025 & Valid \\
\hline K.6.2 & 0,200 & 0,349 & 0,290 & Tidak Valid \\
\hline K.7.1 & 0,451 & 0,349 & 0,012 & Valid \\
\hline
\end{tabular}

\begin{tabular}{|l|l|l|l|l|}
\hline K.7.2 & 0,339 & 0,349 & 0,067 & Tidak Valid \\
\hline
\end{tabular}

Setelah diuji diketahui bahwa terdapat 4 item yang tidak valid yaitu K.1.1, K.3.1, K.6.2 dan K.7.2 maka kriteria tidak valid diuji kembali dengan cara menghilangkan atau membuang item tersebut satu persatu menggunakan SPSS versi 20 dengan hasil akhir sebagai berikut: 


\begin{tabular}{|c|c|c|c|c|}
\multicolumn{7}{|c|}{ Kualitas Produk (Tahap Terakhir) } \\
\hline Item & rhitung & $\begin{array}{c}\mathbf{r}_{\text {tabel }} \\
\mathbf{5 \%} \mathbf{( 3 0 )}\end{array}$ & $\mathbf{S i g}$ & Kriteria \\
\hline K.1.2 & 0,781 & 0,349 & 0,000 & Valid \\
\hline K.2.1 & 0,531 & 0,349 & 0,003 & Valid \\
\hline K.2.2 & 0,490 & 0,349 & 0,006 & Valid \\
\hline K.3.2 & 0,665 & 0,349 & 0,000 & Valid \\
\hline K.4.1 & 0,598 & 0,349 & 0,000 & Valid \\
\hline K.4.2 & 0,397 & 0,349 & 0,030 & Valid \\
\hline K.5.1 & 0,644 & 0,349 & 0,000 & Valid \\
\hline K.5.2 & 0,476 & 0,349 & 0,008 & Valid \\
\hline K.6.1 & 0,407 & 0,349 & 0,025 & Valid \\
\hline K.7.1 & 0,451 & 0,349 & 0,012 & Valid \\
\hline
\end{tabular}

2. Hasil Uji Reliabilitas

\begin{tabular}{|c|c|c|} 
Hasil Semua Uji Reliabilitas \\
\hline Variabel & $\begin{array}{c}\text { Nilai Cronbach } \\
\text { Alpha }\end{array}$ & Status \\
\hline Keputusan Pembelian $(\mathrm{Y})$ & 0,687 & Reliabel \\
\hline Promosi $\left(\mathrm{X}_{1}\right)$ & 0,660 & Reliabel \\
\hline Harga $\left(\mathrm{X}_{2}\right)$ & 0,734 & Reliabel \\
\hline Kualitas Produk $\left(\mathrm{X}_{3}\right)$ & 0,774 & Reliabel \\
\hline
\end{tabular}

Dari tabel di atas dapat diketahui bahwa semua variabel dinyatakan reliabel karena semua nilai Cronbach Alpha tiap variabel $>0,60$.

3. Hasil Uji Regresi Linier Berganda

\begin{tabular}{|c|c|}
\hline \multirow{2}{*}{ Model } & Hasil Uji Regresi Linier Berganda \\
\cline { 2 - 2 } & Unstandardized Coefficients \\
\hline (Constant) & 99,633 \\
\hline Promosi & 0,300 \\
\hline Harga & 0,121 \\
\hline Kualitas Produk & 0,285 \\
\hline
\end{tabular}

Berdasarkan hasil perhitungan dengan menggunakan program IBM SPSS Statistics 20 dapat diketahui persamaan regresi berganda linear yaitu sebagai berikut:

$\mathrm{Y}=$

$99,633+0,300 X \mathbf{1}+0,121 X 2+0,285 X 3$

Dari hasil regresi linear berganda tersebut, dapat dijelaskan sebagai berikut:

a. Konstanta sebesar 99,633 menyatakan bahwa nilai promosi $(X 1)$, harga $(X 2)$, dan kualitas produk (X3) dianggap 0 , maka nilai keputusan pembelian (Y) sebesar 99,633.

b. Koefisien regresi promosi (X1) sebesar 0,300 dan bertanda positif, ini menyatakan bahwa setiap kenaikan promosi (X1) sebesar 1 satuan, maka keputusan pembelian $(Y)$ naik sebesar 0,300 dengan asumsi variabel lain tetap. c. Koefisien regresi harga $(X 2)$ sebesar 0,121 dan bertanda positif, ini menyatakan bahwa setiap kenaikan harga (X2) sebesar 1 satuan, maka keputusan pembelian (Y) naik sebesar 0,121 dengan asumsi variabel lain tetap.

d. Koefisien regresi kualitas produk (X3) sebesar 0,285 dan bertanda positif, ini menyatakan bahwa setiap kenaikan kualitas produk $(X 3)$ sebesar 1 satuan, maka keputusan pembelian (Y) naik sebesar 0,285 dengan asumsi variabel lain tetap.

\section{Hasil Uji Parsial (Uji T)}

\begin{tabular}{|c|c|}
\hline \multicolumn{2}{|c|}{ Hasil Uji Signifikansi Parsial (Uji t) } \\
\cline { 2 - 2 } Variabel & Signifil Uji \\
\hline Promosi & 0,020 \\
\hline Harga & 0,336 \\
\hline Kualitas Produk & 0,028 \\
\hline
\end{tabular}

Berdasarkan tabel di atas, maka hasil uji $\mathrm{t}$ pada penelitian ini dapat dijelaskan sebagai berikut:

a. Promosi

Dilihat dari nilai signifikansi variabel promosi < alpha $(0,05)$ pada tabel di atas nilai signifikansi yang diperoleh sebesar 0,020 hal ini menujukkan bahwa nilai nilai signifikansi $0,020<0,05$, maka dapat disimpulkan hipotesis pertama (H1) diterima yang berarti bahwa promosi $(X 1) \quad$ berpengaruh signifikan terhadap keputusan pembelianSmartphone VIVO (Y) pada masyarakat kota Yogyakarta.

b. Harga

Dilihat dari nilai signifikansi variabel harga > alpha $(0,05)$ pada tabel diatas nilai signifikansi yang diperoleh sebesar 0,336 hal ini menujukkan bahwa nilai nilai signifikansi $0,336>0,05$, maka dapat disimpulkan hipotesis pertama (H2) ditolak yang berarti bahwa harga (X2) tidak berpengaruh terhadap keputusan pembelian Smartphone VIVO (Y) pada masyarakat kota Yogyakarta. 
c. Kualitas Produk

Dilihat dari nilai signifikansi variabel kualitas produk < alpha $(0,05)$ pada tabel di atas nilai signifikansi yang diperoleh sebesar 0,028 hal ini menujukkan bahwa nilai nilai signifikansi $0,028<0,05$, maka dapatdisimpulkan hipotesis pertama $(\mathrm{H} 3)$ diterima yang berarti bahwa kualitas produk (X3) berpengaruh signifikan terhadap keputusan pembelian Smartphone VIVO (Y) pada masyarakat kota Yogyakarta.

5. Hasil Uji Simultan (Uji F)

\begin{tabular}{|c|c|c|} 
Hasil Uji Signifikansi Simultan (uji F) \\
\hline Model & F & Sig \\
\hline Regresion & 8,557 & 0,000 \\
\hline
\end{tabular}

Berdasarkan hasil uji simultan dari tabel di atas menunjukkan nilai signifikansi sebesar $0,000<$ alpha $(0,05)$ maka dapat disimpulkan promosi $(X 1)$, harga $(X 2)$, dan kualitas produk $(X 3)$ secara simultan memiliki pengaruh signifikan terhadap keputusan pembelian (Y).

6. Hasil Uji Koefisien Determinasi

\begin{tabular}{|c|c|}
\hline Hasil Uji Koefisien Determinasi $\left(\boldsymbol{R}^{2}\right)$ \\
\hline Model & R Square \\
\hline 1 & 0,241 \\
\hline
\end{tabular}

Pada tabel di atas dapat dilihat bahwa nilai $R 2$ adalah sebesar 0,241. Hal ini dapat diartikan bahwa variabel independen promosi $(X 1)$, harga $(X 2)$, kualitas produk $(X 3)$ dapat mengukur variabel dependen keputusan pembelian (Y) sebesar $24,1 \%$, sisanya sebesar $75,9 \%$ dipengaruhi oleh variabel lain yang tidak ada dalam penelitian ini.

\section{Pembahasan}

\section{Promosi}

Hasil uji $t$ penelitian ini menyimpulkan bahwa terdapat pengaruh promosi terhadap keputusan pembelian Smartphone VIVO pada Masyarakat kota Yogyakarta. Hal ini dibuktikan dengan nilai signifikansi 0,020 lebih kecil dari alpha 0,05. Hasil penelitian ini sesuai dengan penelitian Gerung (2017) dan Weenas (2013) yang membuktikan hasil penelitian ini bahwa kegiatan promosi dapat meningkatkan mutu produknya dan membuju atau merayu konsumen agar membeli produknya.

2. Harga

Hasil uji $t$ penelitian ini menyimpulkan bahwa tidak terdapat pengaruh harga terhadap keputusan pembelian Smartphone VIVO pada Masyarakat kota Yogyakarta. Hal ini dibuktikan dengan nilai signifikansi 0,336 lebih besar dari alpha 0,05. Hasil penelitian ini bertolak belakang dengan penelitian Gerung (2017), Ratnaningrum (2016) dan Weenas (2013) yang menyatakan bahwa ada pengaruh signifikan antara harga terhadap keputusan pembelian. Tetapi ada penelitian yang mendukung yaitu Apriliani (2013) yang mengatakan tidak ada pengaruh signifikan harga terhadap keputusan pembelian. Penelitian Apriani (2013) dilakukan di toko online industri rumah kreatif Coruscate Unique di Jepang. Dari analisis diatas dapat dijelaskan bahwa keputusan pembelian Smartphone VIVO pada Masyarakat kota Yogyakarta tidak mementingkan tinggi rendahnya suatu harga. Selain itu, harga cenderung tidak berpengaruh secara tidak langsung terhadap keputusan pembelian dikarenakan konsumen akan bersedia membayar dengan harga berapapun yang terjadi. 
3. Kualitas Produk

Hasil uji $t$ penelitian ini menyimpulkan bahwa terdapat pengaruh kualitas produk terhadap keputusan pembelian Smartphone VIVO pada Masyarakat kota Yogyakarta. Hal ini dibuktikan dengan nilai signifikansi 0,028 lebih kecil dari alpha 0,05 . Hasil penelitian ini sesuai dengan penelitian Gerung (2017) dan Weenas (2013) yang membuktikanbahwa kualitas produk berpengaruh signifikan terhadap keputusan pembelian. Hasil ini ditunjukkan dengan penilaian yang baik mengenai kualitas produk yang sesuai dengan kemampuan produk untuk melaksanakanfungsinya yang meliputi kehandalan, daya tahan, ketepatan, kemudahan operasi, dan semakin tinggi kualitas suatu produk akan menyebabkan semakin tingginya tingkat kepercayaan konsumen terhadap produk tersebut, dengan hal ini tingkat keinginan dan kebutuhan konsumen akan mendorong konsumen melakukan pembelian produk tersebut. Tetapi hasil penelitian ini bertolak belaknag dengan Ratnaningrum (2016) yang mengatakan bahwa kualitas produk tidak berpengaruh signifikan terhadap keputusan pembelian.

\section{KESIMPULAN DAN SARAN}

\section{Kesimpulan}

1. Promosi berpengaruh terhadap keputusan pembelian Smartphone VIVO pada masyarakat kota Yogyakarta.

2. Harga tidak berpengaruh terhadap keputusan pembelian Smartphone VIVO pada masyarakat kota Yogyakarta.

3. Kualitas produk berpengaruh terhadap keputusan pembelian Smartphone
VIVO pada masyarakat kota Yogyakarta.

4. Promosi, harga, dan kualitas produk berpengaruh secara simultan terhadap keputusan pembelian pada masyarakat kota Yogyakarta.

\section{Saran}

1. Bagi peneliti selanjutnya dapat menguji model dalam penelitian ini pada konteks yang berbeda, dan apabila menggunakan model yang sama diharapkan item kuesioner disesuaikan dengan tingkat pemahaman responden.

2. Berdasarkan dari hasil koefisien determinasi, peneliti dapat menguji variabel selain promosi, harga, dan kualitas produk untuk melakukan keputusan pembelian.

\section{DAFTAR PUSTAKA}

Alma, Buchari. (2007). Manajemen Pemasaran dan Pemasaran Jasa. Edisi Revisi. Bandung: Alfabeta.

Amilia, Suri dan Oloan Asmara. (2017). .Pengaruh Citra Merek, Harga, dan Kualitas Produk Terhadap Keputusan Pembelian Handphone Merek Xiaomi Di Kota Langsa. Jurnal Manajemen dan Keuangan (Mei), Vol. 6. No. 1.

Apriliani, Erin Puri dam Murwatiningsih. (2013). Pengaruh Risiko dan Harga Terhadap Keputusan Pembelian Melalui Kepercayaan Konsumen. Jurnal Dinamika Manajemen (September). Vol 4.No.2.PP. 184191.

Gerung, Christy, Jantje, sepang, dan Sjendry Loindong. (2017). Pengaruh Kualitas Produk, Harga, dan Promosi Terhadap Keputusan Pembelian Mobil Nissan X-Trail Pada PT. Wahana Wirawan Manado. Jurnal 
EMBA (Juni). Vol 5. No. 2. Hal. 2221-2229.

Griffin, Jill. (2003). Costumer Loyalty:

Menumbuhkan

Dan

Mempertahankan Pelanggan.

Jakarta: Erlangga.

Kotler, Philip. (2001). Manajemen Pemasaran: Analisis, Perencanaan, Implementasi dan Kontrol. Jakarta: Prehallindo.

Kotler, Philip. (2002). Manajemen Pemasaran. Edisi Milenium. Jakarta: Prehallindo.

Kotler, Philip dan Gary Amstrong. (2004). Prinsip-Prinsip Pemasaran. Edisi Kedua Belas. Jakarta: Erlangga.

Kotler, Philip. (2008). Manajemen Pemasaran. Edisi Kedua Belas. Jakarta: Indeks.

Kotler, Philip dan Kevin Lane Keller. (2009). Manajemen Pemasaran. Edisi Ketiga Belas. Jakarta: Erlangga.

Mandey, Jilly. (2013). Promosi, Distribusi, Harga Pengaruhnya Terhadap Keputusan Pembelian Rokok Surya Promild. Jurnal EMBA (Desember). Vol 1. No. 4. Hal. 95-104.

Musthofa, Rian. (2018). Pengaruh Harga, Kualitas, dan Promosi Terhadap Keputusan Pembelian Pada Toko Online Lazada di Daerah Istimewa Yogyakarta. Skripsi. Yogyakarta: Universitas Ahmad Dahlan.

Ratnaningrum, Hesti. (2016). Pengaruh Promosi, Harga, Dan Kualitas Produk Terhadap Keputusan Pembelian Konsumen dalam Pembelian Bahan Bakar Minyak Jenis Pertalite Di Kota Yogyakarta. Skripsi. Yogyakarta: Universitas Sanata Dharma.
Rizki, Ainur Rofiq. (2015). Analisis Pengaruh Kualitas Produk Dan Harga Terhadap Keputusan Pembelian Iphone. Skripsi. Surakarta: Universitas Muhammadiyah Surakarta.

Sugiyono. (2014). Metode Penelitian Kuantitatif, Kualitatif dan $R \& D$. Bandung: Alfabeta.

Sulistya, Widha A. (2014). Analisis Pengaruh Harga, Kualitas Produk, Promosi, dan Kelompok Acuan terhadap Pengambilan Keputusan Pembelian Handphone Android. Skripsi. Semarang: Universitas Diponegoro.

Swastha, Dharmmesta Bashu. (1999). Loyalitas Pelanggan: Sebuah Kajian Konseptual Sebagai Panduan Bagi Peneliti. Jurnal Ekonomi dan Bisnis Indonesia. Vol. 14 No. 3.

Tjiptono, Fandy. (2002). Pengertian Promosi [Online]. Didapatkan: $<$ https://maroebeni.wordpress.com/2 008/09/19/fungsi-promosi-dalampemasaran diakses pada [26 April 2018].

Weenas, Jackson R.S. (2013). Kualitas Produk, Harga, Promosi, dan Kualitas Pelayanan Pengaruhnya Terhadap Keputusan Pembelian Spring Bed Comforta. Jurnal EMBA (Desember). Vol. 1. No. 4. Hal. 607618. 